\title{
THE SHEEP OVARY: REGULATION OF STEROIDOGENIC, HAEMODYNAMIC AND STRUCTURAL CHANGES IN THE LARGEST FOLLICLE AND ADJACENT TISSUE BEFORE OVULATION
}

\author{
R. M. MOOR, MARY F. HAY AND R. F. SEAMARK* \\ Agricultural Research Council Unit of Reproductive Physiology and Biochemistry, \\ 307 Huntingdon Road, Cambridge CB3 0JQ and \\ * Department of Obstetrics and Gynaecology, \\ University of Adelaide, Adelaide, South Australia 5000
}

\section{INTRODUCTION}

Important changes occur in the follicle that is destined to ovulate and also in the surrounding ovarian tissue of sheep during the $72 \mathrm{hr}$ preceding ovulation. It is our purpose to describe the morphological and functional changes that take place in large follicles during the preovulatory period and to relate these to the local ovarian environment and general endocrine status prevailing at this time. A consideration of changes in the structure, blood supply and function of the ovaries in vivo, is followed by a discussion of the functional capacity of the individual ovarian components when isolated and studied in vitro. Against this background, the nature and sequence of events that occur in the preovulatory follicle and the mechanisms which regulate them will be discussed.

\section{STRUGTURAL CHANGES IN THE OVARY BEFORE OVULATION}

The CL regresses rapidly 48-72 hr before ovulation (Deane et al., 1966) and at this stage the ovaries contain one or two large (4-5 mm diameter) activated follicles. The theca interna of these follicles contains many elongated fibroblastlike cells interspersed with large epithelioid cells that have ultrastructural characteristics typical of steroid-secreting cells. The membrana granulosa is composed of 5-15 layers of closely apposed interdigitating cells between which are numerous intercellular junctional complexes; the epithelium rests on a distinct basal lamina (Bjersing et al., 1972).

About $12 \mathrm{hr}$ before ovulation degenerative changes become apparent in the thecal cells, the most outstanding of which is the accumulation of numerous large lipid droplets in the epithelioid cells; some cells become shrunken and electron dense. The membrana granulosa also undergoes striking changes in the preovulatory period (PI. 1, Fig. 1); the cells lose their compact arrangement, the extensive system of junctional complexes is disrupted, some cellular degeneration occurs and the basal lamina breaks down. Numerous processes, 
often bearing microvilli, project from the granulosa cells into the wide intercellular spaces.

During the $72 \mathrm{hr}$ preceding ovulation $\Delta^{5}$ - $3 \beta$-hydroxysteroid dehydrogenase $(3 \beta$-HSD) activity can only be demonstrated histochemically in the large activated follicles (Moor et al., 1971). Enzyme activity is confined to the theca interna where the intensity of the reaction increases as ovulation approaches. Activity of $3 \beta$-HSD has not been observed in the granulosa cells before ovulation.

\section{OVARIAN BLOOD FLOW DURING THE 72 HR BEFORE OVULATION}

\section{Total ovarian blood flow}

Estimations of ovarian blood flow in sheep vary widely from 2 to $20 \mathrm{ml} /$ ovary/min (see Goding et al., 1971). In a careful study by Mattner \& Thorburn (1969), however, ovarian venous flow was found to drop from about $8 \mathrm{ml} / \mathrm{min}$ $72 \mathrm{hr}$ before ovulation to $3 \mathrm{ml} / \mathrm{min}$ at oestrus. Ovarian arterial blood flow also declines two- to three-fold during this period (Moore et al., 1972) and is paralleled by a sharp decline in the flow of lymph from the ovary (Morris \& Sass, 1966).

\section{Intraovarian capillary blood flow}

Since a significant fraction of the total ovarian blood flow may bypass the capillary bed (Baird et al., 1973), it has become imperative to obtain information on intraovarian capillary flow rates. Compartmental flow within the ovary has been determined by the injection of ${ }^{46}$ Sc-labelled microspheres $(15 \mu \mathrm{m}$ diameter) into the left ventricle of 23 sheep during the preovulatory period (Bruce \& Moor, 1975). Total capillary flow to the ovary containing the CL fell during the $72 \mathrm{hr}$ preceding ovulation from $546 \pm 40 \mathrm{ml} \mathrm{min}{ }^{-1} 100 \mathrm{~g}^{-1}$ ovarian tissue to $165 \pm 45 \mathrm{ml} \mathrm{min}-1100 \mathrm{~g}^{-1}$, while capillary flow to the other ovary remained relatively constant at about $170 \mathrm{ml} \mathrm{min}^{-1} 100 \mathrm{~g}^{-1}$ during this period. Changes in the intraovarian distribution of flow in the preovulatory period are characterized by a tenfold decline in luteal flow, a constant stroma flow of about $170 \mathrm{ml} \mathrm{min} \mathrm{m}^{-1} 100 \mathrm{~g}^{-1}$ and a significant increase in follicular flow from about $600 \mathrm{ml} \mathrm{min}^{-1} 100 \mathrm{~g}^{-1}$ to over $1000 \mathrm{ml} \mathrm{min}^{-1} 100 \mathrm{~g}^{-1}$ in the 12-18 hr before ovulation.

The distribution of capillary flow to follicles of different sizes is shown in Table 1. Two important points emerge. Firstly, relative blood flow appears to be inversely related to the mass of the follicular tissue. Secondly, the increase in

\section{EXPLANATION OF PLATE 1}

FIG. 1. Electron micrograph of part of a large follicle obtained from a ewe $6-8 \mathrm{hr}$ before ovulation. Thecal cells (on left) contain numerous lipid droplets. Granulosa cells have separated and follicular fluid fills the wide intercellular gaps. The basal lamina (arrowed) is still intact. $\times 5000$.

Fig. 2. Paraffin-wax section of explant of corpus luteum after 7 days in culture. Haematoxylin and chromotrope $2 R, \times 480$.

Fig. 3. Paraffin-wax section of explant of ovarian stroma after 7 days in culture. One primordial follicle can be seen. Haematoxylin and chromotrope $2 \mathrm{R}, \times 225$. 


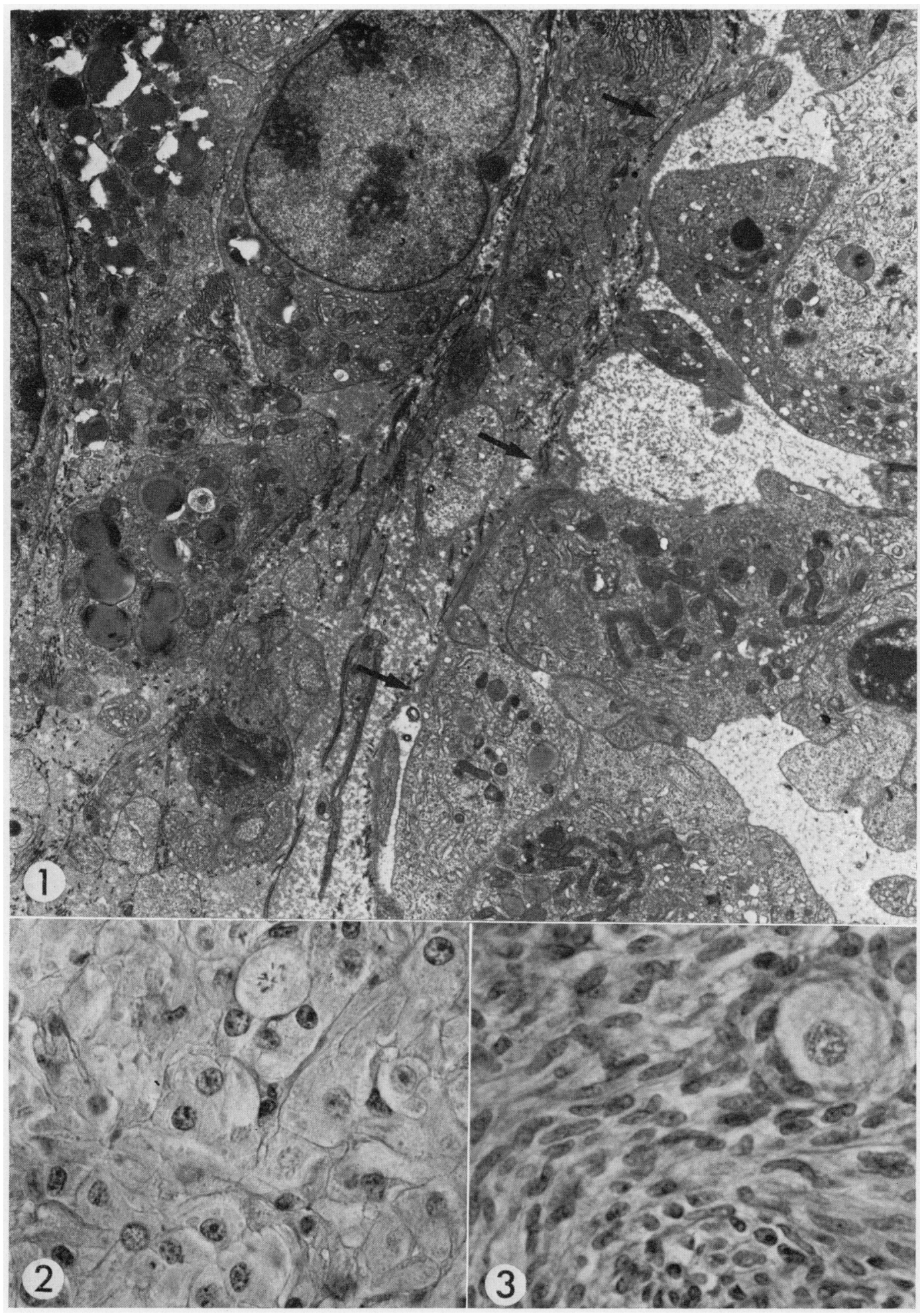

Fucing to. .j96 


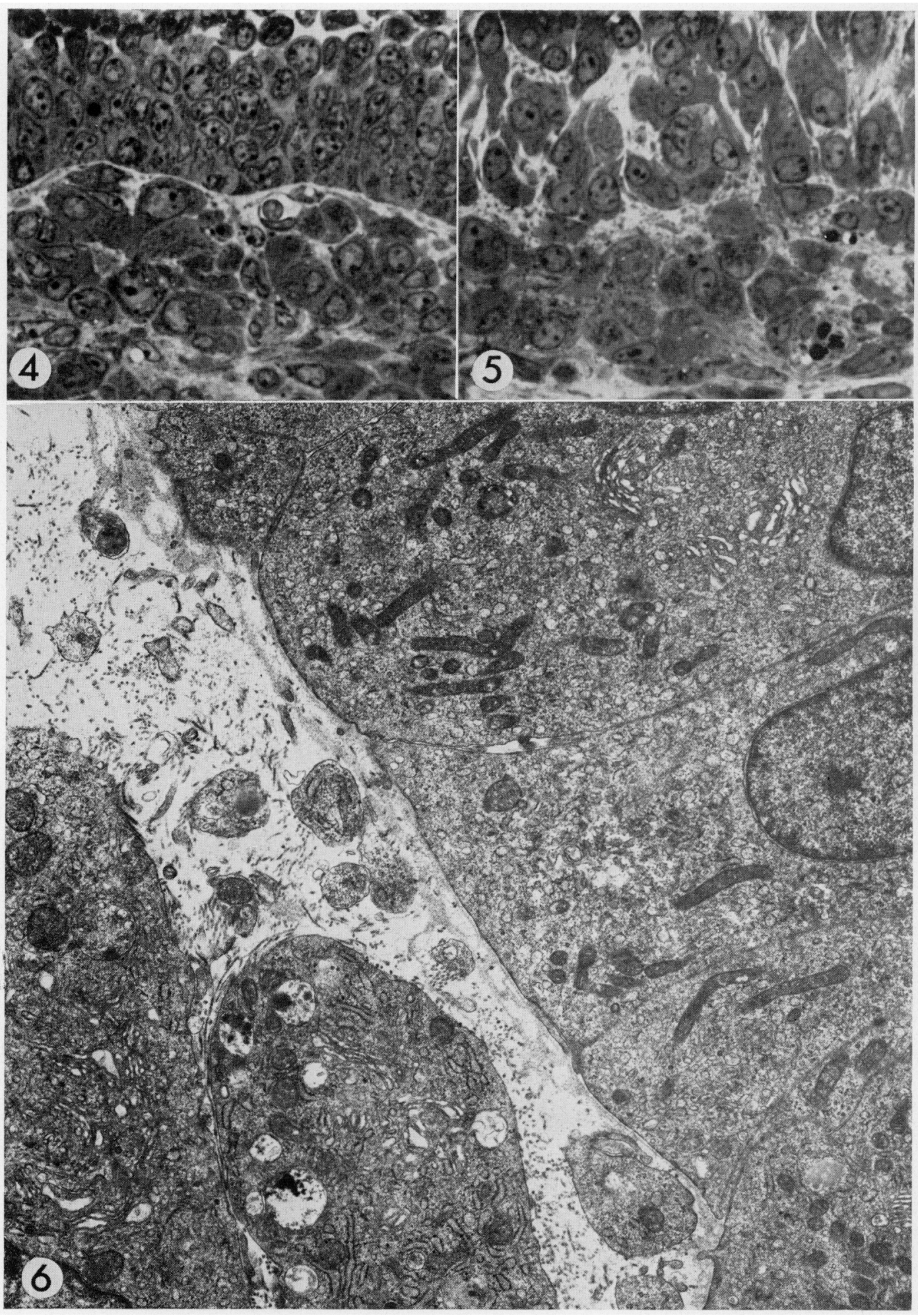


Table 1. Mean capillary blood flow through vessels of less than $15 \mu \mathrm{m}$ in diameter in ovine follicles of different sizes at $72 \mathrm{hr}$ and $12 \mathrm{hr}$ before ovulation (data from Bruce \& Moor, 1975)

\begin{tabular}{ccc}
\hline $\begin{array}{c}\text { Follicular } \\
\text { groups } \\
\text { (mg tissue })\end{array}$ & Follicular blood flow before ovulation (Mean \pm S.E.M.; $\mathrm{ml} \mathrm{min}^{-1} 100 \mathrm{~g}^{-1}$ ) \\
\hline$<1 \cdot 0$ & $72 \mathrm{hr}$ & $12 \mathrm{hr}$ \\
\hline $1 \cdot 0-2 \cdot 0$ & $1003 \pm 303$ & $1575 \pm 354$ \\
$2 \cdot 1-3 \cdot 0$ & $921 \pm 118$ & $1235 \pm 118$ \\
$3 \cdot 1-5 \cdot 0$ & $432 \pm 60$ & $1047 \pm 106$ \\
$5 \cdot 1-10$ & $623 \pm 175$ & $614 \pm 110$ \\
$>10 \cdot 1$ & $460 \pm 148$ & - \\
& $572 \pm 135$ & $886 \pm 135$ \\
\hline
\end{tabular}

follicular flow near the time of ovulation occurs in all classes of follicles. The follicle destined to ovulate, however, receives not only the largest volume of blood in absolute terms ( $\mathrm{ml} / \mathrm{min}$ ), but also, according to Burr \& Davies (1951), has capillaries which are more permeable than those in other follicles.

The high levels of oestrogen and LH secreted around oestrus probably play an important role in increasing the rate of blood flow to the follicles before ovulation. In sheep the administration of $\mathrm{LH}$, but not FSH, growth hormone or prolactin, increases ovarian blood flow by $25-50 \%$ within 30 min of treatment (see McCracken et al., 1971). Likewise, fractional blood flow (\% of cardiac output which perfuses an organ) to the ovaries of rats increases rapidly after $\mathrm{LH}$ injection, and is $66 \%$ above control values within $20 \mathrm{~min}$ of treatment (Wurtman, 1964). The action of LH is specific to the ovary and may act via the local mediation of a vasoactive substance such as histamine (Szego, 1965).

The significance of the increased blood flow to ovine follicles before ovulation is unclear. However, the rapid response of the ovarian microcirculation to LH and the increased metabolic requirements of follicles after gonadotrophin stimulation (Ahrén et al., 1969) suggest that an enhanced vascularity may be an inherent part of the action of LH upon the follicles.

\section{OVARIAN STEROID PRODUGTION DURING THE 72 HR BEFORE OVULATION}

Production in vivo

Involution of the CL and the consequent termination of progesterone secretion occurs within the $36 \mathrm{hr}$ before ovulation (Edgar \& Ronaldson, 1958; Thorburn et al., 1969). By contrast, oestrogen output from the ovary containing

\section{EXPLANATION OF PLATE 2}

Fig. 4. Epon section of oestrogen-secreting follicle cultured for 3 days in control medium. There is a distinct basal lamina between the closely packed granulosa cells above and the theca interna cells below. Toluidine blue, $\times 670$.

Fig. 5. Epon section of large follicle cultured for 3 days in a medium containing $5 \mu \mathrm{g}$ LH/ml. The granulosa cells have separated (above), the basal lamina has disappeared and degenerative changes are visible in the theca interna cells (below). Toluidine blue, $\times 670$. FIG. 6. Electron micrograph of part of a large follicle cultured for 3 days in a medium containing $0.1 \mathrm{mM}$ dibutyryl cyclic AMP. A degenerating cell with residual bodies can be seen in the theca interna (lower left). The membrana granulosa is composed of closely packed cells and has a distinct basal lamina. $\times 7500$. 
the largest follicle increases gradually and reaches a maximal rate of secretion (350 ng/hr) 40-48 hr before ovulation (Cox et al., 1971). The secretion of oestrogen, predominantly oestradiol-17 $\beta$, remains high for a further $20 \mathrm{hr}$ and then declines sharply to low levels at oestrus (Moore et al., 1969; Cox et al., 1971). The precise pattern of androgen secretion in ewes has yet to be described in detail, but available evidence indicates that the output of androstenedione follows closely that described for oestradiol-17 $\beta$ (Baird et al., 1968).

\section{Intraovarian sites of production}

The production of steroids into the culture medium by the three discrete tissue components of the sheep ovary, namely the GL, stroma and follicles, is shown in Text-fig. 1. Luteal tissue obtained from ewes 1 day after ovulation and maintained in organ culture for 1 week retains good structural integrity (Pl. 1, Fig. 2) and produces high levels of pregnenolone, progesterone and $20 \alpha$ hydroxypregn-4-en-3-one into the culture medium. Neither ovine luteal tissue nor monolayers of granulosa cells produced detectable quantities of $17 \alpha$-hydroxylated progestin, androgen or oestrogen in vitro. The ovarian stroma in sheep contains few secretory elements and, although well maintained in organ culture (Pl. 1, Fig. 3), secretes little steroid into the culture medium. By contrast, the large activated follicles produce high levels of oestrogen and androgen in culture. The precise pattern of steroids produced by follicles in vitro varies according to the stage of the cycle at which they are removed from the sheep (Moor, 1973; Seamark et al., 1974).
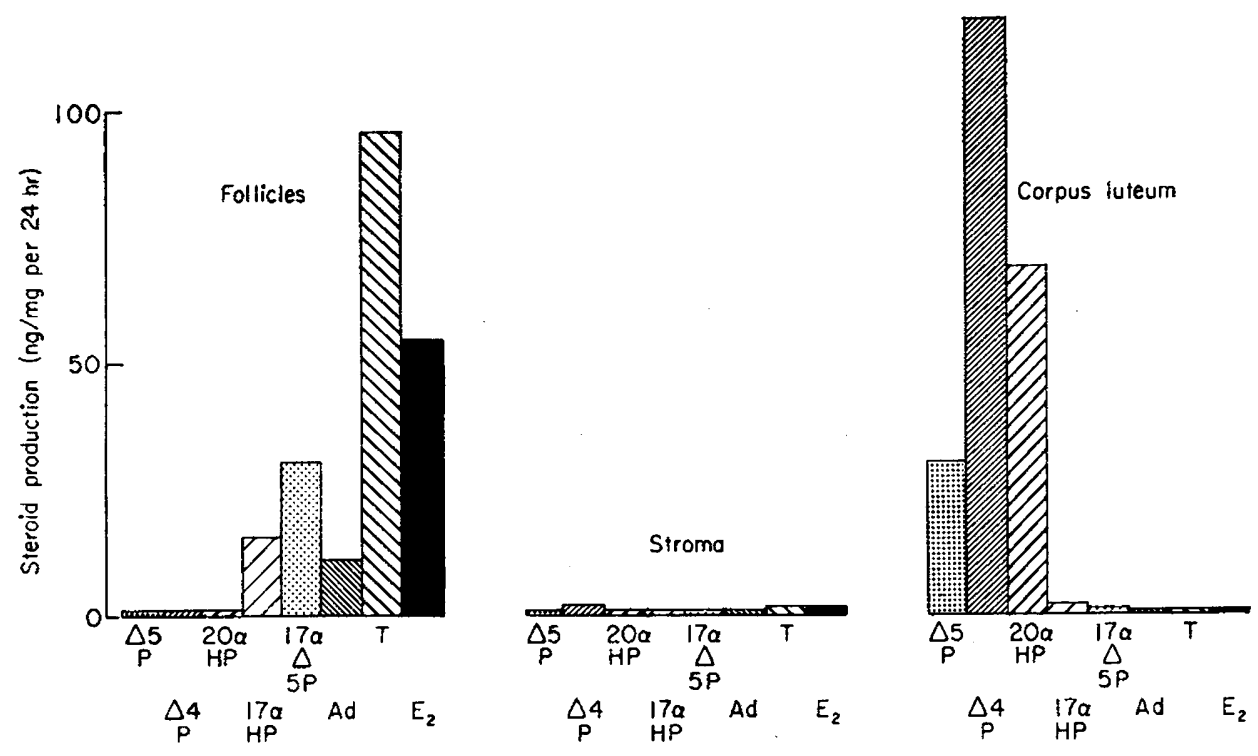

TEXT-FIG. 1. Steroid production by the isolated components of ovaries removed from sheep after ovulation and maintained in tissue culture. $\Delta 5 \mathrm{P}=$ pregnenolone; $\Delta 4 \mathrm{P}=$ progesterone; $20 \alpha \mathrm{HP}=20 \alpha$-hydroxypregn-4-en-3-one; $17 \alpha \mathrm{HP}=17 \alpha$-hydroxyprogesterone; $17 \alpha \Delta 5 \mathrm{P}=17 \alpha$-hydroxypregnenolone; $\mathrm{Ad}=$ androstenedione; $\mathrm{T}=$ testosterone; $\mathrm{E}_{2}=$ immunoreactive oestrogen. 
Production by the preovulatory follicle in vitro

Follicles obtained from ewes either $72 \mathrm{hr}$ or $48 \mathrm{hr}$ before ovulation produce steroid at a mean rate of about $80 \mathrm{ng} / \mathrm{mg}$ follicular tissue per $24 \mathrm{hr}$ over the 7-day culture period. By contrast, follicles removed from ewes 12-18 hr before ovulation produce about $550 \mathrm{ng}$ steroid/mg per $24 \mathrm{hr}$. The large increase in steroid production by follicles explanted after the endogenous release of gonadotrophin is a reflection of a fundamental change both in the type of steroid produced and in the cell type responsible for steroid synthesis (Seamark et al., 1974).

Large activated follicles obtained $72 \mathrm{hr}$ before ovulation secrete high levels of oestrogen (75 ng/mg per $24 \mathrm{hr}$ ) and some androgen, primarily in the form of testosterone, into the culture medium. Oestrogen production is reduced in follicles obtained $36 \mathrm{hr}$ before ovulation but the reduction in $\mathrm{G}_{18}$ steroid production is replaced by an increase in $\mathrm{C}_{19}$ and $17 \alpha$-hydroxylated $\mathrm{C}_{21}$ steroid production. It is probable that the cells of the theca interna are primarily responsible for the synthesis of the above steroids (see Seamark et al., 1974; Hay \& Moor, 1975). Follicles obtained 12-18 hr before ovulation, i.e. after the gonadotrophin surge, secrete little oestrogen or androgen and only a transitory peak of $17 \alpha$-hydroxylated progestin. The virtual cessation of 'thecal steroid' production is, however, accompanied by the production from the luteinized granulosa cells of large amounts of progesterone $(300 \mathrm{ng} / \mathrm{mg}$ per $24 \mathrm{hr}$ ) and $20 \alpha$-hydroxypregn-4-en-3-one ( $250 \mathrm{ng} / \mathrm{mg}$ per $24 \mathrm{hr}$ ).

REGULATION OF STEROID PRODUGTION BY THE PREOVULATORY FOLLICLE Effect of $L H$

It has been reported that the secretion of oestrogen by the large follicle before oestrus induces the release of a large amount of pituitary LH 20-24 hr later (Radford et al., 1969; Goding et al., 1969). We postulate that the resulting high levels of $\mathbf{L H}$ in the blood act back on the preovulatory follicle to inhibit production of steroids by the theca interna and, subsequently, to initiate luteinization and progesterone production by the membrana granulosa (Moor, 1974). The infusion of $1 \mathrm{mg} \mathrm{LH}$ (NIH-LH-S17) into sheep $48 \mathrm{hr}$ before ovulation totally inhibits the rise in oestrogen production that would otherwise occur in the ensuing $24 \mathrm{hr}$. Likewise, oestrogen secretion by large follicles maintained in organ culture is inhibited by the prior infusion of $\mathrm{LH}$ in vivo or its administration in vitro (Text-fig. 2). The sharp drop in oestrogen production in vitro after addition of $\mathrm{LH}$ is followed by a transitory peak first of testosterone then of $17 \alpha$-hydroxylated progestin and finally a large and sustained output of progesterone and 20 $\alpha$-hydroxypregn-4-en-3-one (McIntosh \& Moor, 1973). The decline of oestrogen, androgen and $17 \alpha$-hydroxylated progestin production reflects a progressive loss of synthetic capacity by the cells of the theca interna. This loss in functional ability is accompanied by distinct degenerative changes in the thecal cells visible at both the light and the electron microscope levels. The cytoplasm of the thecal cells becomes vacuolated (Pl. 2, Fig. 5) and contains many autophagic vacuoles and residual bodies. Despite the occurrence of cellular 


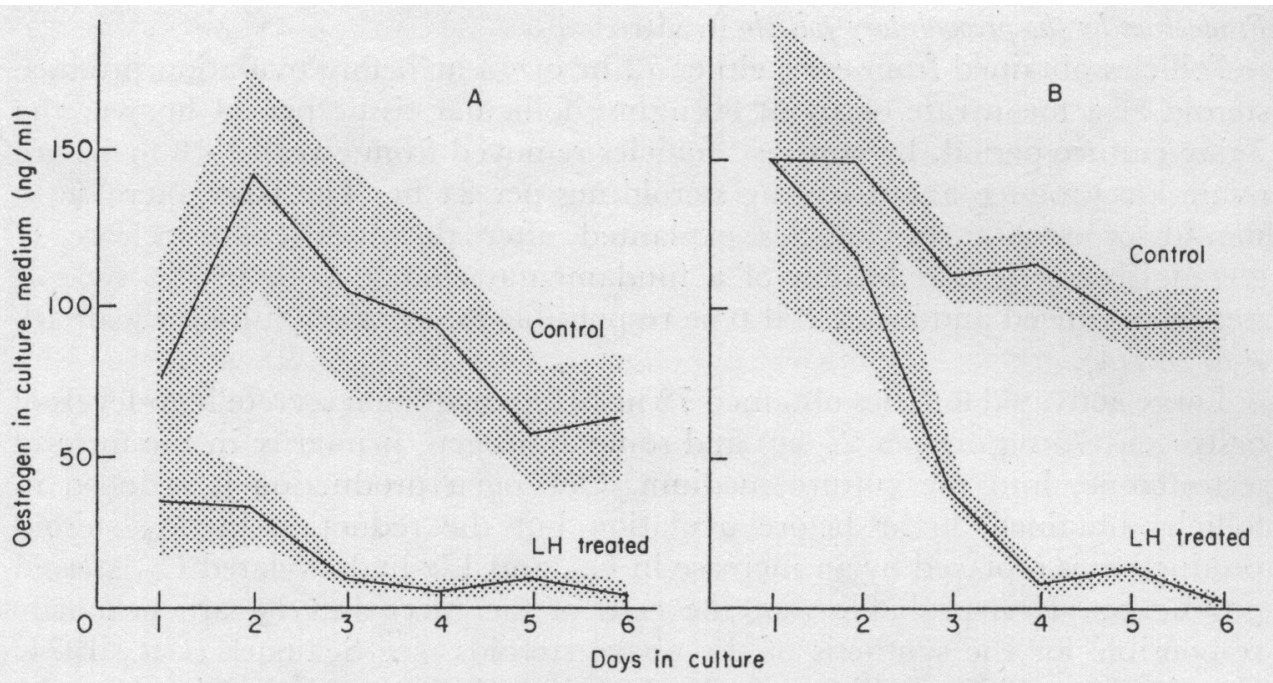

TExT-FIG. 2. Mean oestrogen production ( \pm S.E.M.) from large ovarian follicles maintained in organ culture. (A) Follicles explanted about $48 \mathrm{hr}$ before ovulation: LH-treated follicles were obtained from sheep infused with LH (1 mg NIH-LH-S17) for $6 \mathrm{hr}$ before ovariectomy and control follicles were obtained from sheep infused for the same period with physiological saline. (B) Follicles obtained from sheep $72 \mathrm{hr}$ before ovulation: LH $(5 \mu \mathrm{g} / \mathrm{ml}$ culture medium) was added to the LH-treated follicles $24 \mathrm{hr}$ after explantation but control follicles were cultured in the absence of added hormones. (Data from Moor, 1973.)

degeneration, $3 \beta$-HSD can still be demonstrated in the theca interna at ovulation.

The increase in progesterone and its $20 \alpha$-dihydro derivative is associated with morphological luteinization of the granulosa cells. Initially the cells separate and the basal lamina breaks down (Pl. 2, Fig. 5) in a manner virtually identical with that occurring in vivo 6-12 hr after the peak in endogenous $\mathrm{LH}$ secretion. Within $24-48 \mathrm{hr}$ after the addition of LH to the culture medium, $3 \beta$-HSD activity can be detected in the granulosa cells. After a further 2-3 days in culture these cells regain a more compact arrangement and acquire many of the ultrastructural characteristics of early lutein cells (M. F. Hay \& R. M. Moor, unpublished observations). These changes do not occur in control follicles cultured in the absence of added gonadotrophins (Pl. 2, Fig. 4); under such conditions the theca remains steroidogenically active throughout the culture period, whereas the granulosa cells appear to be virtually inactive.

\section{Cyclic $3^{\prime}, 5^{\prime}-A M P$ as a mediator of the action of $L H$}

There is compelling evidence to support the hypothesis that cyclic AMP plays an important role as a mediator of the action of gonadotrophins on the ovary (see Robison et al., 1971; Lindner et al., 1974). In the sheep, LH significantly increases tissue levels of cyclic AMP in the follicle within 5 min and peak levels $(20 \mathrm{pmol} / \mathrm{mg}$ tissue) are reached within $60 \mathrm{~min}$ of $\mathrm{LH}$ treatment (McIntosh \& Moor, 1973). By analysing the thecal and granulosa elements separately, it has been established that the production of this nucleotide is restricted almost exclusively to the cells of the theca interna (T. Weiss, R. M. 
Moor \& R. F. Seamark, unpublished observations). The cells of the membrana granulosa are apparently unable to synthesize large amounts of cyclic AMP, and the nucleotide which is found associated with the granulosa layer following LH stimulation of entire follicles appears to stem almost entirely from the thecal cells. The response of the intact follicle to cyclic AMP, or its dibutyryl derivative, differs according to the concentration of nucleotide added. When mature follicles are exposed in vitro to low levels of dibutyryl cyclic AMP $(0.1 \mathrm{~mm})$, oestrogen production declines rapidly and is in turn replaced first by testosterone and then by $17 \alpha$-hydroxypregnenolone and pregnenolone (McIntosh \& Moor, 1973). Thereafter almost all steroid production by the follicle ceases;

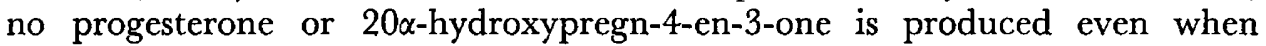
dibutyryl cyclic AMP (10 $\mu \mathrm{g})$ is injected directly into the follicle. When low levels of dibutyryl cyclic AMP are added to monolayer cultures of isolated granulosa cells, however, progesterone production is consistently stimulated, and at a rate significantly in excess of that obtained by the addition of $\mathrm{LH}$ to the cultures (J. E. A. McIntosh, R. M. Moor \& R. F. Seamark, unpublished observations).

The decline in thecal steroid production and the apparent inactivity of the membrana granulosa in follicles exposed to low levels of dibutyryl cyclic AMP is clearly reflected in the ultrastructural changes that occur after treatment (Pl. 2, Fig. 6). Within $24 \mathrm{hr}$, lipid droplets accumulate in the large thecal cells and in a further $48 \mathrm{hr}$ the fibroblasts and the epithelioid cells contain large residual bodies and areas of focal degradation. The membrana granulosa, on the other hand, is morphologically virtually unaffected by cyclic AMP and its appearance is similar to that of follicles cultured in control medium.

An entirely different effect from that described above is obtained when higher levels of dibutyryl cyclic AMP $(0.5-1.0 \mathrm{~mm})$ are added to large follicles in culture. In these follicles the decline in oestrogen production is replaced by the secretion of large amounts of progesterone into the culture medium (80 $\mathrm{ng} / \mathrm{mg}$ follicular tissue per $24 \mathrm{hr}$ ). The foregoing results probably reflect differing sensitivities of thecal and granulosa cells to cyclic AMP.

That cyclic AMP is intimately involved in some of the gonadotrophin-induced changes that occur in follicles before ovulation appears probable. It is tempting to speculate that cyclic AMP formed by the theca cells in response to $\mathrm{LH}$ acts on the granulosa cells as a 'diffusion activator' (Huxley, 1935). Cyclic AMP is generally regarded as an intracellular mediator of protein hormone action. However, release of cyclic AMP into the extracellular compartment has now been reported in several tissues including, most recently, isolated rat ovaries stimulated with LH (Ahrén et al., 1974), and a wider role for cyclic AMP as a diffusion or distance activator must be considered.

\section{Relationship between $L H$ and prostaglandin in follicles}

It has been postulated that prostaglandins, especially those of the E series, are obligatory intermediates between LH and the adenyl cyclase system (Kuehl et al., 1973). We have tested some aspects of this hypothesis using the ovine follicle in culture as a model (R. M. Moor \& R. F. Seamark, unpublished observations). Incubation with indomethacin, aspirin or flufenamic acid, 
agents which block prostaglandin synthesis (see Sanner, 1974) failed to depress the responsiveness of the follicle to subsequent gonadotrophic stimulation. Further experiments have shown that both PGF-2 $\alpha$ and PGE-2 stimulate progesterone production by the cultured follicle; the pattern of steroids secreted after prostaglandin stimulation is, however, significantly different from that seen after the addition of LH, HCG or cyclic AMP to cultured follicles. Perhaps most opposed to the Kuehl hypothesis (Kuehl et al., 1973) is our finding that the effects of PGE-2 and LH on tissue levels of cyclic AMP are clearly additive (T. Weiss, R. M. Moor \& R. F. Seamark, unpublished observations). These findings support those of other workers (see Kolena \& Channing, 1972; Lindner et al., 1974) and suggest that prostaglandins are unlikely to be obligatory intrafollicular mediators of $\mathrm{LH}$.

Table 2. Effect of HCG and inhibitors of the aromatase enzyme system on the mean daily production of progesterone by large follicles obtained from untreated sheep between Days 4 and 14 of the cycle and maintained in organ culture for 5 days

\begin{tabular}{|c|c|c|c|}
\hline \multirow{2}{*}{$\begin{array}{l}\text { Treatment of } \\
\text { follicles in vitro }\end{array}$} & \multicolumn{3}{|c|}{ Progesterone production (Mean \pm S.E.M.; $n g m g^{-1} 24 h r$ ) } \\
\hline & Day 1 & Day 3 & Day 5 \\
\hline Control & $4 \cdot 0 \pm 0 \cdot 7$ & $7 \cdot 7 \pm 2 \cdot 6$ & $9 \cdot 0 \pm 1 \cdot 8$ \\
\hline HCG 20 i.u. $\mathrm{ml}^{-1}$ & $4 \cdot 0 \pm 0.7$ & $87 \cdot 7 \pm 9 \cdot 6$ & $90 \cdot 4 \pm 9 \cdot 6$ \\
\hline $\begin{array}{l}\text { Androst-1,4,6-triene- } \\
3,17 \text {-dione }(0.4 \mathrm{~mm})\end{array}$ & $3 \cdot 6 \pm 0 \cdot 8$ & $79 \cdot 1 \pm 15 \cdot 5$ & $46 \cdot 5 \pm 17 \cdot 0$ \\
\hline $\begin{array}{l}\text { Testosterone acetate } \\
\quad(0.4 \mathrm{~mm})\end{array}$ & $3 \cdot 8 \pm 0 \cdot 9$ & $81 \cdot 4 \pm 11 \cdot 7$ & $32 \cdot 1 \pm 7 \cdot 1$ \\
\hline
\end{tabular}

\section{Effect of $L H$ on the enzyme system responsible for aromatization}

Indirect evidence obtained by determining the rate of substrate accumulation in preovulatory follicles has indicated that the aromatase and then the desmolase system limit steroid production in the theca interna before ovulation (Seamark et al., 1974). A similar approach has been used to monitor possible changes in the activity of key enzymes after LH treatment. In control follicles obtained from sheep $72 \mathrm{hr}$ before ovulation, oestrogen is produced in large amounts and there is little evidence of significant enzyme impedence. However, after the addition of LH to follicles in culture, oestrogen output from the theca declines and substrate for the aromatase system accumulates rapidly. The susceptibility of the aromatase system to $\mathrm{LH}$ can also be inferred from the radioisotope studies of Rado et al. (1970). These workers found that the infusion of LH in vivo resulted in a temporary increase followed by a sharp fall in the rate of conversion of $\mathrm{C}_{19}$ androgen to $\mathrm{C}_{18}$ oestrogen.

To examine the role of the aromatase system in the regulation of steroidogenesis further, we have undertaken experiments in which the aromatizing enzymes in large follicles have been inhibited with testosterone acetate or andros-1,4,6-triene-3,17-dione (R. M. Moor \& R. F. Seamark, unpublished observations). Untreated follicles secrete high levels of oestrogen into the culture medium but almost no progesterone (Table 2). The addition of 
HCG (or LH) to the medium increases progesterone production rapidly; maximal levels of progesterone are reached within $48 \mathrm{hr}$ of the addition of the gonadotrophin. A similar large and rapid increase in progesterone production occurs in follicles cultured in the presence of aromatase inhibitors. However, in the absence of gonadotrophin the large output of progesterone is not sustained and is significantly lower than that of the HCG-treated group 4 days after treatment. Stimulation of progesterone production in intact follicles in the absence of gonadotrophin can also be induced by the addition of testosterone or androstenedione to the culture medium. These findings suggest that androgens secreted by the theca interna may facilitate the action of $\mathrm{LH}$ or cyclic AMP in promoting steroidogenesis in the membrana granulosa.

\section{CONCLUDING REMARKS}

The processes involved in the transformation of the preovulatory follicle from an oestrogen- to a progesterone-secreting organ are dependent upon the release of pituitary gonadotrophin at oestrus. However, crucial changes take place within the follicle before the gonadotrophin surge; the follicle develops steroidogenic competence, becomes the predominant source of oestrogen synthesis and acquires the ability to respond fully to $\mathrm{LH}$, possibly by the selective development of extensive receptor capacity.

There are probably multiple sites at which LH exerts its action on the follicle. Intraovarian changes in the microcirculation, the relative permeability of follicular capillaries, and the level of cellular metabolism are under hormonal regulation. LH influences the availability and distribution of steroid precursors, it promotes the formation of cyclic AMP in the theca interna and ultimately initiates granulosa cell luteinization and progesterone production. By contrast, LH destroys the structural and functional integrity of the theca interna; the enzyme system responsible for aromatization is inhibited, steroid production declines and cellular degeneration occurs.

The obligatory role of cyclic AMP in mediating some, but not all the intrafollicular effects of LH has been demonstrated and a special role for the nucleotide as a distant diffusion activator of the granulosa cells proposed. We have, however, found no evidence to suggest that prostaglandin F-2 $\alpha$ or prostaglandin E-2 are mediators of the action of $\mathrm{LH}$ on the adenyl cylase system.

\section{REFERENCES}

Ahren, K., HAMBerger, L. \& Rubenstein, L. (1969) Acute in vivo and in vitro effects of gonadotrophins on the metabolism of the rat ovary. In The Gonads, pp. 327-354. Ed. K. W. McKerns. AppletonCentury-Grofts, New York.

Ahrén, K., Herlttz, H., Nilsson, L., Perklev, T., Rosserg, S. \& Selstam, G. (1974) Gonadotrophins and cyclic AMP in various compartments of the rat ovary. In Gonadotrophins and Gonadal Functions, p. 364. Ed. N. R. Mougdal. Academic Press, New York.

Baird, D.T., Goding, J.R., Ichikawa, Y. \& McGracken, J.A. (1968) The secretion of steroids from the autotransplanted ovary in the ewe spontaneously and in response to systemic gonadotrophin. F. Endocr. 42, 283-299.

Baird, D.T., Giles, M. \& Cockburn, F. (1973) The $\mathrm{PO}_{2}, \mathrm{PCO}_{2}, \mathrm{pH}$ and oxygen content of ovarian venous blood of sheep. F. Endocr. 57, 405-411.

Bjersing, L., Hay, M.F., Kann, G., Moor, R.M., Naftolin, F., Scaramuzzi, R.J., Short, R.V. \& YoungLAI, E.V. (1972) Changes in gonadotrophins, ovarian steroids and follicular morphology in sheep at oestrus. F. Endocr. 52, 465-479. 
BRuce, N.W. \& MooR, R.M. (1975) Ovarian follicular blood flow in the sheep. F. Reprod. Fert. 43, 392-393.

BuRR, J.S.T. \& Davres, J.I. (1951) The vascular system of the rabbit ovary and its relationship to ovulation. Anat. Rec. 111, 273-297.

Cox, R.I., MAtTnER, P.E. \& ThorburN, G.D. (1971) Changes in ovarian secretion of oestradiol-17 $\beta$ around oestrus in the sheep. F. Endocr. 49, 345-346.

Deane, H.W., HAy, M.F., Moor, R.M., Rowson, L.E.A. \& Short, R.V. (1966) The corpus luteum of the sheep: relationship between morphology and function during the oestrous cycle. Acta endocr., Copenh. 51, 245-283.

EdgaR, D.G. \& Ronaldson, J.W. (1958) Blood levels of progesterone in the ewe. F. Endocr. 16, 378-384.

Goding, J.R., Gatt, K.J., Brown, J.M., Kaltenbach, G.C., Cumming, I.A. \& Mole, B.J. (1969) Radioimmunoassay for ovine luteinizing hormone. Secretion of luteinizing hormone during estrus and following estrogen administration in the sheep. Endocrinology 85, 133-142.

Goding, J.R., Baird, D.T., Cumming, I.A. \& McGracken, J.A. (1971) Functional assessment of autotransplanted endocrine organs. Acta endocr., Copenk., Suppl. 158, 169-199.

HAY, M.F. \& MOOR, R.M. (1975) Relationships between structure and function in Graafian follicles of sheep. F. Reprod. Fert. 45, 583-593.

Huxley, J.S. (1935) Chemical regulation and the hormone concept. Biol. Rev. 10, 427-441.

Kolena, J. \& Channing, C.P. (1972) Stimulatory effects of LH, FSH and prostaglandins upon cyclic $3^{\prime}, 5^{\prime}$-AMP levels in porcine granulosa cells. Endocrinology 90, 1543-1550.

Kueht, F.A., Cirillo, V.J., HAM, E.A. \& Humes, J.L. (1973) The regulatory role of the prostaglandins on the cyclic $3^{\prime}, 5^{\prime}$-AMP system. Adv. Biosci. 9, 155-172.

Lindner, H.R., Tsafariri, A., Lieberman, M.E., Zor, U., Кoch, Y., Bauminger, S. \& Barnea, A. (1974) Gonadotrophin action on cultured Graafian follicles: induction of maturation division of the mammalian oocyte and differentiation of the luteal cell. Recent Prog. Horm. Res. 30, 79-138.

McCracken, J.A., Baird, D.T. \& Goding, J.R. (1971) Factors affecting the secretion of steroids from the transplanted ovary in the sheep. Recent Prog. Horm. Res. 27, 537-582.

MaInTosh, J.E.A. \& MooR, R.M. (1973) Regulation of steroid secretion in sheep ovarian follicles. 7. Reprod. Fert. 35, 605-606.

MATTNER, P.E. \& Thorburn, G.D. (1969) Ovarian blood flow in sheep during the oestrous cycle. 7. Reprod. Fert. 19, 547-549.

Moor, R.M. (1973) Oestrogen production by individual follicles explanted from ovaries of sheep. $\mathcal{F}$. Reprod. Fert. 32, 545-548.

MooR, R.M. (1974) The ovarian follicle of the sheep: inhibition of oestrogen secretion by luteinizing hormone. 7. Endocr. 61, 455-463.

MooR, R.M., HAY, M.F. \& CAlDwell, B.V. (1971) The sheep follicle: relationship between sites of steroid dehydrogenase activity, gonadotrophic stimulation and steroid production. 7 . Reprod. Fert. 27, 464-485.

Moore, N.W., Barrett, S., Brown, J.B., Schindler, I., Smith, M.A. \& Smyth, B. (1969) Oestrogen and progesterone content of ovarian vein blood of the ewe during the oestrous cycle. $\mathcal{F}$. Endocr. 44, 55-82.

Moore, R.T., Mohrman, D.E. \& Niswender, G.D. (1972) Variations in blood flow to the ovaries of sheep during the oestrous cycle. Proc. 4th Int. Congr. Endocrinology, pp. 64-65. Excerpta Medica Int. Congr. Ser. No. 256.

MorRIs, B. \& SAss, M.B. (1966) The formation of lymph in the ovary. Proc. R. Soc. B 164, 577-591.

Radpord, H.M., Wheatley, I.S. \& WalLACE, A.L.C. (1969) The effects of oestradiol benzoate and progesterone on secretion of luteinizing hormone in the ovariectomised ewe. F. Endocr. 44, $135-136$.

Rado, A., McCracken, J.A. \& Batrd, D.T. (1970) The formation of oestrogens by the autotransplanted ovary of the ewe perfused in vivo with ${ }^{\circ} \mathrm{C}_{19}$ steroids. Acta endocr., Copenh. 65, 244-260.

Robison, G.A., Butcher, R.W. \& Sutherland, E.W. (1971) Cyclic AMP. Academic Press, New York.

SANNER, J.H. (1974) Substances that inhibit the action of prostaglandins. Archs intern. Med. 133, $133-146$.

Seamark, R.F., Moor, R.M. \& McIntosh, J.E.A. (1974) Steroid hormone production by sheep ovarian follicles cultured in vitro. F. Reprod. Fert. 41, 143-158.

Szego, C.M. (1965) Role of histamine in mediation of hormone action. Fedn Proc. Fedn Am. Socs exp. Biol. 24, 1343-1352.

Thorburn, G.D., Bassett, J.M. \& SMrth, I.D. (1969) Progesterone concentration in the peripheral plasma of sheep during the oestrous cycle. 7 . Endocr. 45, 459-469.

WuRTMAN, R.J. (1964) An effect of LH on the fractional perfusion of the rat ovary. Endocrinology 75, 927-933. 